\title{
The Determinants of Export Performance: The Case Study of Zanzibar Export
}

\author{
Drama Bedi Guy Hervé ${ }^{1}$, Grafoute Amoro ${ }^{2}$, Rahma Salim Mahfoudh ${ }^{3} \&$ N'guessan Bi Zambe Serge Constant ${ }^{4}$ \\ ${ }^{1}$ Department of Economics, Université Peleforo Gon Coulibaly de Korhogo, Republic of Cote d'Ivoire \\ ${ }^{2}$ Economics Shanghai University, Shanghai, China \\ ${ }^{3}$ Minister of Finance and budget, Zanzibar \\ ${ }^{4}$ African Graduate School of Information Technology and Communication, Republic of Cote d'Ivoire \\ Correspondence: Drama Bedi Guy Hervé, Department of Economics, Université Peleforo Gon Coulibaly de \\ Korhogo, Republic of Cote d'Ivoire. Tel: 225-0427-8959 or 225-0767-8754. E-mail: \\ dramsiben.upgck@gmail.com
}

Received: March 18, 2014

Accepted: April 7, 2014

Online Published: May 25, 2014

doi:10.5539/ijef.v6n6p95

URL: http://dx.doi.org/10.5539/ijef.v6n6p95

\begin{abstract}
This study seeks to examine and analyze the prominent factors that affect Zanzibar's export performance. Specifically this study looks at the impact of human capital development in developing the Zanzibar economy, analyzes the contribution of FDI in boosting export activities and lastly evaluates the price effect of major export products in export performance. We analyze the determinants of Zanzibar's export performance and the analysis is carried out using Ordinary Least Square method, on time series data covering the period 1980-2005. The study also examines how the factors have been influencing Zanzibar export performance.
\end{abstract}

Keywords: export performance, price effects, export determinants, OLS model, export products

\section{Introduction}

Export performance cannot be only the good fortune for simply producing goods which are highly demanded. Rather it is likely to be the outcome of the combination of various factors integrating the supply capacity and or access to international markets. Equally important, it is necessary to identify such elements and their degree of importance in determining the export performance. For the last two decade trade barriers kept on falling as a result of trade negotiation under the WTO context and autonomous reforms proposed by the Britton Wood institutions to developing economies aimed at promoting International trade. Despite this improved market access conditions, concerns have remained on the necessity to improve the supply capacity largely by developing economies.

In general export performance has varied substantially across countries, World exports increased by almost 220 per cent in the past twenty years. The figure jumps to 720 per cent for East Asian and Pacific countries and falls to 80 per cent for Sub-Saharan countries. The exports of "best performers", such as the Republic of Korea, China, Cambodia and Viet Nam, have grown by more than 15 per cent annually over the whole period. "Worst performers", mostly African and Latin American countries, have negative annual growth rate records in at least one decade. Consequently the level of economic growth has remained relatively low and in some cases stagnant. The export performance of Sub-Saharan Africa (SSA) over the last three decades has not been encouraging. In fact, SSA has lost its share of world exports by over $250 \%$ over the last 30 years (Lyakurwa, 1998). Many of the SSA countries have been experiencing poor export performance. The reason for such performance is the export portfolio of these countries, which depends on particular commodities. Most African countries depend on two or three main primary commodity exports for the bulk of their export exchange earnings, and they have had to contend with the problem of long-term instability of primary commodity prices, which is greater than that of prices for non-primary tradable commodities (UNCTAD, 2003). Exports of primary commodities account for between 80 and 90 per cent of the total exports of many African countries and the long term decline in prices, variability of export volume, deterioration in the terms of trade, and the instability of commodity markets are said to be major factors that affect export earnings (export performance) and constrain economic growth and poverty reduction in Africa (Adebusuyi, 2004). 
While developed countries strengthen their exports by concentrating on more value added products, Africa, particularly Sub-Saharan Africa has not been able to move from dependence on the export of primary commodities to manufactured products (Lyakurwa, 1998). The letter offer better prospects for export earnings, allow for more rapid productivity growth and expansion of production and hold out the promise of greater stability as volume expands, thereby avoiding terms of trade that have frustrated the long term growth performance of many developing economies. This creates a challenge for most of developing countries, especially those dependent on commodities for their export earnings and growth, as to how to shift away from their dependence on the export of primary commodity towards greater production and export of industrial products so that their foreign earnings can stabilize. Tanzania (Zanzibar) is among the Sub-Saharan African countries and exports are the main source of foreign exchange for the economy. Its export structure has been characterized by greater concentration on a few traditional commodities such as cloves, copra, chilies, clove steam oil and seaweed. From the total export of the country, cloves are the dominant export commodities accounting for about 60 percent of earnings on average over the last twenty-five years. However, clove production and exports have been declining dramatically in recent years (Economic Research Bureau, 2003).

The overall performance of the export sector was satisfactory during 1960s and 1970s as the performance of cloves was impressive. This was helped by favorable export prices and high export volumes. The earnings from cloves at that time were able to finance the Zanzibar Development Budget by $89 \%$ in the 1978/79 fiscal period (Shella, 1979), and in 1980 a total of Tshs. 497million from the total export earning of Tshs. 559.6 million was generated from the sales of cloves.

Currently, falling prices in world markets and the fall in agricultural productivity attributable to insufficient extension services, production bottlenecks which include seasonal variation due to climatic changes, the shrinking of clove farm size, underutilization of capacity of clove processing firms, low farm gate price, and a limited and unstable market for Zanzibar products. These factors contribute to the poor performance of agriculture export performance and growth in general (BOT, 2005). Due to unsatisfactory performance in the agricultural sector, particularly the clove industry, the government's attempt to increase the country's foreign exchange earnings by pursuing concrete policy measures and looking for other alternatives for obtaining revenue, and thus tourism becomes an important source of foreign earnings in Zanzibar to supplement the revenue loss. The remain part of this paper is divided in three (3) sections. We deal with estimation methodology, the regression framework and data sources in section two (2). Section three (3) elucidates the empirical results and interpretations then the last section concludes.

\section{Estimation Technique, Regression Analysis of the Model and Data Sources}

\subsection{Estimation Technique}

The Ordinary Least Square estimation technique is used in this study. The choice of this technique is due to its simplicity, convenience and the fact that it has been successfully used by other studies and gives out meaningful results. The parameters obtained using this OLS technique is best, linear and unbiased (BLUE).

Non-stationary time series data has often been regarded as a problem in empirical analysis. Working with non-stationary variables leads to spurious regression results from which further inference is meaningless when these variables are estimates in their levels. In order to overcome this problem there is a need for testing the stationarity of these micro-economic variables. The unit root is performed in order to determine time series characteristics. This test is important as it shows the number of times the variable has to be differenced to arrive at a stationary value. In general, economic variables which are stationary are called I (0) series and those which are to be differenced once in order to achieve a stationary value are called I (1) series. Classical econometric theory assumes that observed data come from a stationary process, where means and variances are constant over time implying that both are not a function of time. For a given set of non-stationary variables, their means and variances are functions of time. Testing for stationary provides an analysis for the summary of description statistics.

\subsection{Unit Root Test}

Modern time series analysis has established that regression with non-stationary variables may lead to nonsense regression results (Hendry \& Juselius, 2000). These regression results might indicate the existence of extremely high correlation between variables; therefore there is no ready causal explanation. The recent development of unit root in econometrics has facilitated addressing the problem in a more constructive way. In order to avoid specious regression results, stationary value of these series is important. The Unit root test is a current approach used to conduct stationary tests. This study uses the ADF unit root test for presence of unit root. 


\subsection{Theoretical Framework of the Model}

In an attempt to investigate the determinants of Zanzibar export performance, the study considers export performance as defined by Mndeme (1981) as "the amount earned from export across different products". Therefore export performance means export earnings. This study uses the Simple Regression model to determine the factors that affect Export performance (Ep). For the simplicity and accuracy of the results of the study, seven factors are identified as variables that affect the export performance of the Zanzibar.

Therefore the export equation can be expressed as follow:

$$
E P=f(F D I, E X P, F G P, E X D, H C D, F D I, I N C, P D N, \Omega)
$$

Where:

$\mathrm{EP}=$ Export earning;

$\mathrm{EXP}=$ Export price of major product (cloves);

$\mathrm{FGP}=$ Farm gate price;

$\mathrm{EXD}=$ Export demand;

$\mathrm{HCD}=$ Human capital development;

$\mathrm{INC}=$ World income;

FDI $=$ Foreign Direct Investment;

PDN = Clove Production;

$\Omega=$ Dummy variable to capture other factors that affect export performance.

Thus the export performance model can be specified in a linear relationship through a regression equation as follow:

$$
E p=\alpha_{0}+\alpha_{1} F D I+\alpha_{2} E X P+\alpha_{3} F G P+\alpha_{4} E X D+\alpha_{5} H C D+\alpha_{6} I N C+\alpha_{7} P D N+\Omega
$$

Where: $\mathrm{FDI}>0, \mathrm{EXP}>0, \mathrm{FGP}>0, \mathrm{HCD}>0, \mathrm{INC}>0$ and $\mathrm{EXD}>0, \mathrm{PDN}>0$.

The study used the same approach used by previous researchers who investigated the determinant of a country's export performance. However some modification is made to reveal the Zanzibar situation.

\subsection{Hypothesis to be Tested}

Is testing the hypothesis of zero influence of independent variables to dependent variable. It attempt to find out whether the independent variables have significant influence on dependent variable or not, that is $\boldsymbol{\alpha}_{\mathbf{i}}$ is significantly equal to zero or not. Mathematically, this hypothesis can be written as:

$\mathbf{H}_{0}: \boldsymbol{\alpha}_{\mathbf{i}}=\mathbf{0}$;

$\mathbf{H}_{\mathbf{i}}: \boldsymbol{\alpha}_{\mathbf{i}} \neq \mathbf{0}$.

\subsection{Data Type and Source}

The study will utilize annual secondary time series data covering the period 1980-2005. This period has been chosen because data to be used in the export earning function is available.

Data for export price, farm gate price, export demand, export earnings, clove production Foreign Direct Investment, human capital development, and world income were collected from the Zanzibar State Trading Corporation (ZSTC), Zanzibar Investment Promotion Agency (ZIPA), Chief of the Government statisticians, publications and websites.

\section{Empirical Result and Interpretation}

\subsection{Empirical Result}

A descriptive analysis of the data which are presented in table 3 was conducted. Usually normally distributed variables give better results than variables which are not normally distributed. The table presents the normality test of the variables. It was found that some of the data are not normally distributed as shown in the table 1 below. 
Table 1 . The summary of the descriptive statistic of the data

\begin{tabular}{lllllllll}
\hline & FGP & EP & EXP & EXD & FDI & HCD & INC & DPN \\
\hline Mean & 5749132 & 2120298 & 645993 & 1345246 & 1951397 & 25462.8 & 689940 & 5281.71 \\
Median & 4719690 & 1533617 & 10990 & 3679.3 & 2355966 & 18001.5 & 294830 & 4348.42 \\
Max & 2060717 & 8346618 & 4730128 & 3486500 & 4043745 & 59609.0 & 2729708 & 16051.82 \\
Mini & 15641.4 & 3458195 & 13.960 & 12.000 & 0.00000 & 13116.0 & 45445 & 41.4600 \\
Std. Dev. & 5662637 & 2103873 & 1319984 & 6836716 & 7896443 & 15298.7 & 800883.1 & 4674.985 \\
Skew ness & 0.82190 & 1.885234 & 2.2573 & 4.7999 & 4.73162 & 1.18087 & 1.22896 & 0.70979 \\
Kurtosis & 2.81484 & 5.484390 & 6.962 & 24.039 & 23.6019 & 2.92084 & 3.20316 & 2.358 \\
Jarque-Bera & 2.96439 & 22.08768 & 39.093 & 579.41 & 556.824 & 6.04950 & 6.58962 & 2.629 \\
Probability & 0.22713 & 0.000016 & 0.0000 & 0.0000 & 0.00000 & 0.04857 & 0.03707 & 0.26855 \\
\hline Sorc: Own
\end{tabular}

Source: Own calculation using data from regression analysis.

In addition to the descriptive statistics, the analysis to test linear relationships among the variables was conducted using a Correlation Matrix. The result of this test is presented in Table 2 below.

Table 2. Correlation matrix

\begin{tabular}{cccccccc}
\hline & DPN & FGP & EXPRC & EXPVOL & FDI & HC & INC \\
\hline DPN & & 0.75055 & 0.23623 & 0.470045 & 0.24669 & -0.22096 & -0.30543 \\
FGP & 0.75055 & & 0.59726 & 0.09334 & -0.03865 & -0.09060 & -0.20524 \\
EXP & 0.23623 & 0.59726 & & -0.09807 & -0.12394 & -0.30521 & -0.39072 \\
EXD & 0.47004 & 0.09334 & -0.09807 & & -0.05025 & -0.162493 & -0.10970 \\
FDI & 0.24669 & -0.03865 & -0.12394 & -0.05025 & & 0.128991 & 0.025062 \\
HCD & -0.22096 & -0.09060 & -0.30523 & -0.16249 & 0.12899 & & 0.96623 \\
INC & -0.30543 & -0.20524 & -0.39072 & -0.10970 & 0.025062 & 0.96623 & \\
\hline
\end{tabular}

Source: Own computation from the data used in regression analysis.

The statistics above indicate that there is a strong significant relationship between the world income (INC) and human capital development (HCD). This finding supports the theoretical postulation of the fact that human infrastructure is a key determinant of sustainable development, which results in increased world economic growth and income in general. On other hand, HCD has a weak negative relation to domestic production (DPN). This can be explained by the fact that many of educated people in African countries are reluctant to engage in agricultural activities and they prefer to remain unemployed when they fail to find work in a modern sector. Another significant relationship of 75 percent was found between farm gate prices (FGP) and domestic production (DPN). The motivation effect that price has can be the explanation of this relationship. This is due to the fact that whenever producers are highly paid for their production, they are motivated to produce more and devote their time and resources to the production so that their production capacity can be increased. Apart from that, FGP prove to have a strong and positive relation with export price (EXP). The 59 percent relationship found between the two can be only explained by statistical reasons and not economic reasons. A weak but significant relationship was found between FDI and human capital development (HCD). Generally, FDI when it comes it accompanied by a group of valuable resources such as technology, organizational capability, managerial skills and marketing know-how, all of these in one way or another assist in human capital development.

On the other hand, a weak relationship can be found, at 5 percent and 24 percent, between the EXD and FDI and DPN and FDI respectively. This is due to the reason that the increasing of FDI particularly in Zanzibar is associated with an increase of FDI in the services sector and that causes many people who are involved in production to shift to the services sector. This could be explained by inter alia the factor that the services sector is highly paid compared to other sectors, resulting in low agricultural outputs which in turn contribute to a decline in agricultural and manufacturing activities leading to a decrease in export volume.

In addition to that, the statistics show the insignificant relationship between export volume (EXD) and export price (EXP). This finding is contrary to the economic laws (law of supply). According to this law the increase in price of exported products (EXP) would lead to an increase in the export volume (EXD) that is the quantity supplied to foreign markets. Also the study reveals a significant relationship of 10 percent between the income of the importing countries and the export price. There is no economic reason to justify this; hence we assume the 
result to be the product of computation effect (Statistical reason).

\subsection{Unit Root Test Results}

This part presents and discusses the result of the unit root test on each of the variables in the model. The Augmented Dickey Fuller test for the presence of unit root is performed on the variables levels and the results are presented in Table 3 .

Table 3. Unit root test results: at levels

\begin{tabular}{lcc}
\hline Variables & ADF Test Statistic & Order of Integration \\
\hline EPE & -2.766694 & $\mathrm{I}(0)^{* * *}$ \\
EXP & -1.610885 & $\mathrm{I}(1)$ \\
EXV & -2.849574 & $\mathrm{I}(0)^{* * *}$ \\
FDI & -2.595408 & $\mathrm{I}(1)$ \\
HCD & -0.827178 & $\mathrm{I}(1)$ \\
INC & 0.47372 & $\mathrm{I}(1)$ \\
FGP & -2.807073 & $\mathrm{I}(0)^{* * *}$ \\
DPN & -4.880237 & $\mathrm{I}(0)^{*}$ \\
\hline
\end{tabular}

Note. (i) McKinnon (1980) critical values are used for rejection of the null unit root.

(ii) $\mathrm{I}(0)=$ The variable is stationary, $\mathrm{I}(1)=\mathrm{A}$ variable is integrated of order one

(iii) Critical value for ADF: $* 1 \%$ and $* * * 10 \%$ are -3.7343 and -2.6348 respectively.

Table 4. Unit root test results: at fist difference

\begin{tabular}{lcc}
\hline Variable & ADF Test Statistic & Order of Integration \\
\hline EPE & -4.857666 & $\mathrm{I}(0)^{*}$ \\
EXP & -6.13626 & $\mathrm{I}(0)^{*}$ \\
EXV & -5.945476 & $\mathrm{I}(0)^{*}$ \\
FDI & -4.312052 & $\mathrm{I}(0)^{*}$ \\
HCD & -4.073403 & $\mathrm{I}(0)^{*}$ \\
INC & -3.804415 & $\mathrm{I}(0)^{*}$ \\
FGP & -6.061932 & $\mathrm{I}(0)^{*}$ \\
DPN & -8.725594 & $\mathrm{I}(0)^{*}$ \\
\hline
\end{tabular}

Note. (i) McKinnon (1980) critical values are used for rejection of the null unit root.

(ii) $\mathrm{I}(0)=$ the variable is stationery, $\mathrm{I}(1)=$ A variable is integrated of order one.

(iii) Critical value for $\mathrm{ADF}: * 1 \%$, is -3.7497 .

The results shows that variables for FGP, EXV and EPE are stationary at this level and the remaining variables were not stationary. This means that the test for unit root was to be performed at first difference to test the stationarity for the variables which were not stationary. The result is presented in Table 4 bellow.

\subsection{Interpretation and Discussion of the Econometric Result of Export Performance Equation}

The general model shows that most of the variables are insignificant in explaining the determinant of export performance. Therefore all variables whose t-statistic is less than 2 have been eliminated without losing valuable information and will not appear in the preferred model. Only variables whose t-statistic is greater or equal to 2 will be shown on the preferred model in Table 4 below. 
Table 4. Estimation of OLS result of the preferred model

\begin{tabular}{lcccc}
\hline Explanatory variable & Estimated Coefficients & Std.Error & t-Statistic & Prob \\
\hline C & 0.078045 & 0.153022 & 0.510027 & 0.6186 \\
DLNFDI & -0.188629 & 0.057785 & -3.264346 & 0.0062 \\
DLNFGP & -0.223052 & 0.097989 & -2.276292 & 0.0404 \\
DLNEXP & 0.318681 & 0.096727 & 3.294652 & 0.0058 \\
\hline
\end{tabular}

Source: own computation using the data from the chief of the Government statistician, ZIPA, ZSTC, website.

Note. (i) $\mathrm{D}$ at the beginning of the variable implies Difference; (ii) $\mathrm{R}^{2}=0.54$, prob (F-Statistic) $=0.0103625, \mathrm{DW}=1.76$ and $\mathrm{n}=25$.

Following the leaving out of insignificant variables in the general model without losing valuable information, the preferred model passes the Misspecification and serial correlation test and reports significant F-test statistics, implying that there is an improvement in the overall significance of the model. All variables are significant. The Export price of exported products (DlnEXP) and foreign direct investment (DlnFDI) were significant at 1 percent level while farm gate price (DlnFGP) was significant at 5 percent level.

The obtained $\mathrm{R}^{2}$ in the preferred model of 0.54 implies that the explanatory variables included in the model explain more than 54 percent of all variations in export performance. The Probability of rejecting the model specification given by Prob (F-statistics) of 0.0103625 reflects that the model is well specified. In case the model is adjusted the $\left(\mathrm{R}^{2}\right)$ will be reduced to 54 percent, which still is still preferable in explaining the model variation and thus according to the result we can accept the null hypothesis that the export performance of commodity of the country.

Most of the variables in the model were considered in the determination of export performance in Table 7.

The coefficient of export price of exported products (DlnEXP) was positive as expected and statistically significant at 1 percent level. These indicate that a one percent increase in the price of exported products (DlnEXP) would lead a more than 31 percent increase in income to exporting countries. The justification for this is lies in on the economic concept of revenue whereby an increase in the price of a product sold ceteris paribus would lead to an increase of revenue from the product. This result is contrary to the result found by Musila (2004) where he analyzes the impact of the common market for Eastern and Southern Africa on Kenya export, and finds that export earning growth is associated with high volume exported and not high price for the product.

The negative influence of the foreign direct Investment (DlnFDI) has shown the negative sign different from what has been hypothesized. However its coefficient is statistically significant at one percent level. This implies that, a rise of 1 percent in foreign direct investment (DlnFDI) leads to a decline in export performance of 18 percent.

The possible explanation of this result is that FDI attracted to Zanzibar is not focused in expanding clove exports and agricultural in general, but rather a large percentage of it is allocated to the services sector (for example from 1987 to 2004 out of 425 total investment in Zanzibar only 16 percent was invested in the manufacturing and agricultural sector) in which they have a direct impact on export, compared to 52 percent invested in services sector (tourism activities only) that does not have a direct impact on exports.

Another possible explanation for this could be explained by the fact that most of FDI comes in developing countries especially in Sub-Saharan Africa are resource seeking or market base FDI which is motivated by the availability of natural resources in host countries or wants to by pass trade barrier and to capture domestic market (tariff jumping investment), these type of investment can not lead to a better export performance for the host countries.

The Negative coefficient of farm gate price (FGP) on export performance was realized at five percent significant level. This result is contrary to the prediction above that an increase in farm gate price will result in an increase in export performance. The possible explanation for this is the de-motivation effect that the price has towards farmers.

Apart from having fluctuation trends in farm gate price which cause income uncertainty for the farmers who depends on cloves for their livelihood, the gap between export price and farm gate price discourages clove farmers from fully participating in clove production. For example in 1997 out of 416418.8 shillings generated from selling of clove in each tonne, only 28.96117 shillings was given to the farmers for their selling to ZSTC which is less than one percent of the export price. In 2003, out of the 1934247 shillings of export price per tonne only 218.1387 shillings was given to farmers, which is equivalent to 0.009 percent. As a result farmers neglect 
their farm and engaged in other activities that are paid higher than clove production or they sell their cloves on the black market in where the price is higher than that offered by ZSTC.

Another explanation for this negative result is that there is a possibility of people shifting to other growing service sectors like tourism. Given this, since there is no substantial increase in farm gate price for cloves, people will opt not to concentrate on clove production rather they shift to these sectors.

\section{Conclusion}

The central focus of this study was to investigate the determinants of Zanzibar's export performance and highlight the saliencies of the clove industry and possible area for intervention in order to promote growth in export sector. The study is carried out using Ordinary Least Square (OLS) method, on time series data covering the period 1980-2005. E-View 6.1 was used for econometric analysis. The Jarque-Bera test statistic and Unit root Test were conducted to test for normality and stationarity of the data respectively. The test found that some of the data are not normally distributed but all variables are stationary at level except for human capital development which was differentiated at order one. Lastly, the export performance preferred model was generated and analyzed.

The study reveals that the export price of exported products, has a positive impact on export performance as it was hypothesized and is statistically significant at one and five percent level. This finding is contrary to Musila (2004) findings in investigating Kenya export to COMESA while FDI and farm gate price variables have responded negatively to export performance. The FDI result was contrary to the findings of Sharma (2000), Suh and Khan (2003) who found a positive relationship between FDI and export performance, this study showing that FDI was insignificant in improving export performance.

Zanzibar export is dominated by and strongly depends on clove exportation which contributes more than 50 percent to total export earnings in Zanzibar. Therefore the performance of Zanzibar export depends heavily on clove exportation. Problems in the clove industry and in the agricultural sector in general have an adverse effect on the Zanzibar economy as its economy is declining in real terms. In addition to that the future of the clove through continuous dependence on the Indonesia market as a raw material for cigarette production is uncertain and not apparent in the current situation, due to the declining trend in the cigarette industry caused by increasing awareness of the danger to consumers health and safety.

The price of cloves (major exported product) as revealed by the study is an important factor in generating income for the government and for farmers. The fluctuation in the price of the product leads to earnings instability for the Government and acts as an impediment in undertaking economic development programs, and to farmers who solely depend on this product for their livelihood. They in turn shift to other activities thus contributing to the worsening of the Zanzibar situation in its efforts improving its export and economy in general.

\section{References}

Adebusuyi, B. S. (2004). Stabilization of Commodity Market of Interest to Africa. Abuja Nigeria: Central Bank of Nigeria.

Bank of Tanzania. (2003, 2004, 2005). Operations Report, Dar es Salaam: Annual Report Chief of the Government Statistician. Zanzibar Statistical Abstracts (from 1984 to 2004). Zanzibar: Annual report.

Economic Research Bureau. (2003). The Zanzibar Clove Industry. Report to Ministry of Finance and Economic Affairs, Revolutionary Government of Zanzibar, Zanzibar.

Economic Research Bureau. (2004). Zanzibar clove development strategy and review of ZSTC. A final report presented to Ministry of Finance and Economic Affairs, Revolutionary Government of Zanzibar, Zanzibar.

Flanagan, R. (2003). Labour standard and international competitive advantage. In R. Flanagan (Ed.), International Labor Standards: Globalization, Trade and Public from Experience Towards Strategy. Development Economics Research Policy, Stanford, California: Stanford University Press.

Fleming, E., \& Blowes, A. (2003). An Assessment of Commodity Export Performance in South Pacific Countries, 1960 to 1999. University of New England Graduate School of Agricultural and Resource Economics, Working Paper No 2003-3.

Fugaza, M. (2004). Export performance and its determinant: supply and demand constraints. Policy issues on International Trade and Commodity Study Series No 26 Group, World Bank, Washington, DC.

Kucera, D., \& Sarna, R. (2004). Child labour, education and export performance. Statistical Development and 
Analysis Unit, Working Paper No.52.

Lanjouw, P., \& Feder, G. (2001). Rural non-farm activities and rural development: From experience towards strategy. Development Economics Research.

Liu, X., \& Shu, C. (2001). Determinants of Export Performance and the Effect of the WTO Entry on Labour intensive Exports: Evidence from China's Manufacturing Industry. University of Luton, Hong Kong.

Lyakurwa, W. M. (1998). Primary exports and primary processing for export in sub-saharan Africa. A Paper presented at the AERC/UNU Conference on Asia Global and Africa on Economy, Tokyo, August 3-4.

Marks, D. (2005). The Service Sector in Indonesia's National Accounts, 1951-2000. International Institute of Social History, Indonesia.

Mndeme, F. (1981). Determinant of export performance: The case of Tanzania manufacturing firms. Unpublished M.A Dissertation, University of Dar es Salaam.

Morrissey, O., \& Mold, A. (2006). Explaining Africa's Export Performance-Taking a New Look. Discussion paper 2006.

Musila, J. W. (2004). The common market for Eastern and Southern Africa and Kenya's Export Trade. International Journal of Social Economics, 31(1/2). http://dx.doi.org/10.1108/03068290410515420

Nunnenkam, P. (2002). Foreign direct investment in developing countries: What economists (Don't) know and what policymakers should (not) do! Jaipur, India, CUTS Centre for International Trade, Economics \& Environment D-217.

Redding, S., \& Venable, A. J. (2002). Explaining cross-country export performance: International Linkages and Internal Geography. Seminar paper.

Sharma, K. (2000). Export growth in India: Has FDI played a role? Charles Sturt University, Discussion paper No 816.

Shella, A. M. A. (1979). Declining of clove yield in Zanzibar. Institute of development Management Mzumbe, Research paper.

Suh, T., \& Khan, O. J. (2003). The effect of FDI inflows and ICT infrastructure on exporting in ASEAN/AFTA countries: A comparison with other regional blocs in emerging markets. International Marketing Review, 20(5), 554-571. http://dx.doi.org/10.1108/02651330310498780

UNCTAD Commodity Branch Virtual Institute. (2006). Training package on economics of commodities production and trade. Module 4, Market Access and Market Entry, Geneva.

UNCTAD. (2003). Economic development in Africa; Trade performance and commodity dependence. Geneva, United Nation.

UNCTAD. (2005). Developing countries in international trade, trade and development index 2005. New York and Geneva, United Nations.

UNCTAD. (2006). The least developed countries report, 2006. New York and Geneva, United Nations.

Van, M. (2002). The determinant of export performance in developing countries: The case study of Indonesia manufacturing. Technische Universiteit Eindhoven, The Netherlands Working Paper 02.01.

Wan AbdRa'of, R. (2005). Foreign Direct Investment (FDI) in Malaysia slide presentation. Zanzibar Investment Policy Zanzibar,

Zhang, K. H. (2005). How does FDI affect a host country's export performance? The case of China. Illinois State University, USA

\section{Note}

Note 1. Marco furgazza 2004 export performance and its determinants: supply and demand constraints.

\section{Copyrights}

Copyright for this article is retained by the author(s), with first publication rights granted to the journal.

This is an open-access article distributed under the terms and conditions of the Creative Commons Attribution license (http://creativecommons.org/licenses/by/3.0/). 